\title{
Landscape and Urbanism in the 21st Century. Some Reflections on the State of Affairs
}

\author{
Verónica Benedet ${ }^{1}$ | Arturo Azpeitia ${ }^{2}$ | Agustín Azkarate ${ }^{3}$
}

Received: 2019-10-17 | in its final version: 2020-04-09

\begin{abstract}
For several decades, the notion of landscape has been instrumentalised by various fields of study and with the most diverse views and interests. This is a notion that brings together all the features of liminal spaces, areas characterised by their mediating nature. The success and rapid extension of the concept of landscape, however, has not yet seen a similar development in the methodological field nor is it achieving sufficient consensus to be applied to the administrative scope. In this contribution we will adjust our reflection around the idea of historic urban landscapes, highlighting the need to address the "change management" approach demanded by $21 s t-c e n t u r y$ cities. To this end, we shall delve into some new urban management initiatives, in which the "prosumer citizenship" is beginning to be a key element in the construction of the identity of the spaces inhabited. In the same vein, the scope and content of the emerging discipline of tactical urbanism will also be discussed, paying special attention to the limitations of "design thinking" in historic city centres; areas affected by environments that are frequently problematic, where the complex regulations of -individual or collective- tutelage that cultural assets require come into play.
\end{abstract}

Keywords: Historic Urban Landscapes; Prosumer Citizenship; Tactical Urbanism; City Prosperity Initiative (CPI)

Citation

Benedet, $V$ et al. (2020). Landscape and Urbanism in the 21st Century. Some Reflections on the State of Affairs. ACE: Architecture, City and Environment, 15(43), 8987. DOI: http://dx.doi.org/10.5821/ace.15.43.8987

\footnotetext{
${ }^{1}$ Architect, Ph.D., UNESCO Chair on Cultural Landscape and Heritage (ORCID: 0000-0002-5583-9909) 2 Archaeologist, Ph.D. University of Basque Country, UPV/EHU (ORCID: 0000-0001-5741-6136; WOS Researcher ID: AAO-3655-2020), ${ }^{3}$ UNESCO Chair on Cultural Landscape and Heritage director, University of Basque Country, UPV/EHU (ORCID: 0000-0002-0240-4960). Contact e-mail: arturo.azpeitia@ehu.eus
}

ACE, 15 (43) CC BY-ND 3.0 ES | UPC Barcelona, España | Landscape and Urbanism in the 21 st Century. Some Reflections on the State of Affairs. DOI: http://dx.doi.org/10.5821/ace.15.43.8987 


\section{Preliminary issues}

The semantic evolution of the concept of landscape has a long history. From its original aesthetic connotations, the term has been incorporating diverse meanings in the light of the concerns and the prevailing fashions of society: at first very slowly and, in the last two decades, at great speed as we shall see.

Following the line of research established in previous works (self-citation 2016, 2018), where the notion of historic urban landscapes has been questioned based on a critical approach, this contribution goes deeper into the subject by focusing on new recent initiatives that are being discussed. The content of Recommendation CM/REC(2017) $7^{1}$ will also be addressed. This document expressly formalises the current trend that links the concept of landscape to issues such as democracy, sustainable development or human rights; issues that no one disputes, but which require some consideration. Recognising that "landscapes constitute a complex of material and non-material connotations that science has separated” (CM/REC(2017)7, page 96) may be an idea of unquestionable seminal value, but by itself, it does not contribute much to the construction of a methodological apparatus that is more necessary than ever in a general context dominated by the socio-economic dimension and globalising dynamics.

\section{The Beginnings: Monument and Surroundings}

Since the end of the 19th century, a discourse developed in Europe that focused primarily on the protection of monuments (Choay, 1992; Jokilehto, 1999). It was not until the first third of the 20th century, with the emergence of scientific restoration headed by Gustavo Giovannoni, that a new sensibility began to be clearly vindicated, which also focused its attention on the care of the areas surrounding historical buildings (Giovannoni, 1931). This idea was explicitly expressed in the Athens Charter for the Restoration of Historic Monuments (1931), which in point 7 of its main resolutions recommends that "attention should be given to the protection of areas surrounding historic sites".

The Recommendation concerning the Safeguarding of Beauty and Character of Landscapes and Sites (UNESCO, 1962) was the first international document that explicitly referred to the concept of urban landscape by claiming that "Protection should not be limited to natural landscapes and sites, but should also extend to landscapes and sites whose formation is due wholly or in part to the work of man. Thus, special provisions should be made to ensure the safeguarding of certain urban landscapes and sites which are, in general, the most threatened, especially by building operations and land speculation. Special protection should be accorded to the approaches to monuments." (General Principles, no. 5).

Two years later, the Venice Charter (ICOMOS, 1964) insisted on the same idea that "the concept of a historic monument embraces not only the single architectural work but also the urban or rural setting" (art. 1).

From then on, the concept of historical buildings and their surroundings as a whole was widely accepted, as can be seen in a large number of regulatory documents: Convention Concerning the Protection of the World Cultural and Natural Heritage of 1972, the European Charter of the Architectural Heritage of 1975, the Nairobi Recommendation of 1976, the Quito Colloquium of 1977 ,

\footnotetext{
1 Council of Europe, European Landscape Convention. Contribution to human rights, democracy and sustainable development. October 2018.
}

ACE, 15 (43) CC BY-ND 3.0 ES | UPC Barcelona, España | Landscape and Urbanism in the 21st Century. Some Reflections 2 on the State of Affairs. DOI: http://dx.doi.org/10.5821/ace.15.43.8987 
the Toledo Charter of 1986, the International Charter for the Conservation of Historic Towns and Urban Areas of 1987 (Washington Charter). This latter document also included a systemic approach that sees a city as a whole, as a historical entity and as a social and dynamic ensemble that requires coherent economic and social development policies. It also recognises some of the key aspects of transformation processes affecting urban areas (impact of tourism, a decline of craft activities, gentrification, etc.).

It would take a few more years and extensive discussions for the sixteenth session of the World Heritage Committee in Santa Fe (1992) to adopt the "Operational Guidelines for the Implementation of the World Heritage Convention" and introduce a new category: Cultural Landscapes.

\section{From the Protection of the Exceptional to the Management of the Ordinary}

The new millennium brought important innovations with the unveiling of two key documents on the issues we are studying. The first of these, the Krakow Charter, reminds us, for example, that "in many societies, landscapes are historically related to urban territories and influences. The integration of cultural landscape conservation, and the sustainable development of regions and localities with ecological activities, and the natural environment require awareness and understanding of the relationships over time. This involves making links with the built environment of the metropolis, city and town" (art. 9).

However, it was the European Landscape Convention (ELC) which eventually became the key document, with its now famous definition of landscape as "an area, as perceived by people, whose character is the result of the action and interaction of natural and/or human factors" (Article 1, a). This expansion of the concept in the fields of heritage and landscape also brought about an expansion of the duties of the public administrations which, going beyond the almost nineteenth-century interest in protecting relevant monuments and exceptional landscapes, incorporated to their tasks the daily management of the "ordinary", a much wider and therefore much more complex universe. It should be remembered that this awareness of everyday, degraded, and even forgotten elements in relation to landscape management predates the ELC. The notion of "ordinary landscape" appeared as early as 1989 (Luginbühl, 1989; Sansot, 1989)2, marking the first turning point from a protectionist/patrimonial landscape tradition and a political understanding of them (regarding "Paysages Ordinaires/Ordinary Landscapes" you can consult, in addition to papers cited above, Groth and Bressi (1997), Muñoz (2008 and 2010), and Papadam (2017).

Making this qualitative leap is not easy, however, and it can be said that it is still an unfinished process today. Managing ordinary territories requires rethinking traditional approaches and developing new methodological strategies; all this in a historic moment in which global change, the formidable growth of cities, the voracious real estate appetite of neoliberal capitalism or the unstoppable development of various kinds of citizens' movements, has led to a new way of approaching problems and the reordering of traditional priorities. Some authors, such as N. Smith, had already warned us in advance when they pointed out that we are facing the emergence of a new type of urbanism in which "urban aspects are being dramatically redefined" (2001, p. 25) and in which former conceptual contenders are failing everywhere.

\footnotetext{
${ }^{2}$ cit. by Temple-Boyer (2014: 85).
} 
It was these problems arising from this new context that the International Conference on World Heritage and Contemporary Architecture (Vienna Memorandum, 2005) wished to address. The diagnosis of the obsolescence of international regulations, useless in the face of the unstoppable growth and transformation of cities at the global level, was accepted by UNESCO. Consequently, the goal could only be to draft a new document that attempted to reconcile the apparently contradictory dynamics of permanence and change, favouring the renewal of the historic urban fabric with the incorporation of contemporary architectural contributions (Conti, 2009). As one of its authors would later point out, the goal was to create a text that would be recognised in the future for its capacity to carry out a dialogue on contemporary development in historic cities (van Oers, 2010, p.9), thus launching "the first attempt in twenty years to review and update the modern paradigm of urban conservation" (Bandarin \& Van Oers, 2014, p. 121). From that meeting resulted the so-called Vienna Memorandum, which introduced the Historic Urban Landscape concept into the international arena. A controversial text and concept like few others, to the extent that it is considered to be one of the most widely debated and questioned conservation documents of our time (Ibidem, p. 276).

After Vienna 2005, this discussion has been extremely intense, resulting in various approaches and continuous reformulations at numerous international meetings. Among the most fruitful were the regional meetings held by the UNESCO World Heritage Centre in Jerusalem (Israel, 2006), St. Petersburg (Russia, 2007), Olinda (Brazil, 2007), Chandigarh (India, 2007), Zanzibar (Tanzania, 2009) and Rio de Janeiro (Brazil, 2009). Finally, the 2011 Paris Recommendation on Historic Urban Landscape agreed on the current definition of Historic Urban Landscape, understood as "the urban area understood as the result of a historic layering of cultural and natural values and attributes, extending beyond the notion of "historic centre" or "ensemble" to include the broader urban context and its geographical setting" (point 8).

In recent years, the Historic Urban Landscape concept has been used as a conceptual framework of reference by professionals from many disciplines related to the field of urban conservation. This has led to the emergence of biased and partial understandings, reducing the scope to their specialities, which has led to the "abuse" of the concept itself, making it practically impossible to cover all its aspects in a single definition. The imprecise nature of cultural manifestations as a "migratory concept" (Caraballo Perichi, 2009, p. 61) in permanent transformation, also adds to the confusion when developing the idea of historic urban landscapes and trying to clearly define their objectives, scope and value; since, despite the fact that the historic part of a city is articulated on a specific space, its historic scope and continuous transformations are much more difficult to define, to the point that every landscape becomes a cultural package, a depository of history, and a space to interpret the world (Carapinha, 2009).

\section{Speech Goes One Way and Reality the Other ${ }^{3}$}

Historical cities, their spaces and their landscape are not static. The elements that compose them constitute a systemic whole in which historical and contemporary dimensions coexist. The correct management of urban heritage requires the clear awareness of this dichotomy in order to address all the aspects that affect its development with guarantees: the new role that cities play in the global economy, the need to promote urban sustainability, the pressure of tourism, climate change, a concept of cultural heritage in continuous transformation, the significance of intangible values, the insertion of contemporary architecture, etc.

\footnotetext{
${ }^{3}$ Azkarate and Azpeitia, 2016: 320.
}

ACE, 15 (43) CC BY-ND 3.0 ES | UPC Barcelona, España | Landscape and Urbanism in the 21st Century. Some Reflections 4 on the State of Affairs. DOI: http://dx.doi.org/10.5821/ace.15.43.8987 
Although there is no discussion regarding the Historic Urban Landscape concept from a theoretical standpoint, its practical realisation is much more problematic. The commitment to the dynamism that the urban phenomenon poses in the 21st century and the assumption of change as a consubstantial part of modern cities, constitute the core of all the difficulties. There is no consensus on what the acceptable limit to change should be in historic urban landscapes. In this regard, we must cite some authoritative figures that have most clearly expressed themselves on this subject, warning of the dangers of this situation: "in the case of the Historic Urban Landscape, the justification that is used (that we face new challenges that require new concepts to face them) and, above all, the implications derived from broadening a field that is already extensive and ill-defined, and absences that can be detected in various documents, generate a deep uneasiness, since they convert an approach based on the concept of Historic Urban Landscape into something very difficult to apply (...) and an empty and banal rhetoric. And in this situation, vagueness and generalities are interpreted as a sign of weakness, as a demonstration of everything that can ultimately be done" (Lalana, 2011, p. 17).

This is extremely dangerous in a global context in which the large capitals and the laws of the market and consumption set the tone for urban management and planning policies. The dominance of the free market that is characteristic of the modern world has turned cities into important assets to exploit their investment advantages. In this sense, the concept of "creative destruction" used by the Austrian economist Schumpeter to reflect the essence of capitalism, takes on special relevance when explaining the appropriation of urban space by the insatiable interests of financial capital (self-citation 2019).

\section{We Have a Problem}

That conceptual convergence around the notion of landscape that slowly began to emerge in the nineteenth century in an attempt to overcome the traditional Manichean view of nature and culture has assumed a holistic understanding that, in its totalising view, is leading us all to a dead end.

The European Landscape Convention of the year 2000 brought with it the idea of the "common landscape", of the "heritage of the ordinary", realities that are nourished by everyday elements, without a striking singular value, shaping a reality far removed from the traditional aesthetic canons, linked both to historic cities and, especially, to their urban peripheries. In recent years, the difficulty in managing all of this through typical protection regimes has become evident.

The 2011 Paris Recommendation on the Historic Urban Landscape further complicated matters by defining the concept of Historic Urban Landscape ${ }^{4}$, as: "the urban area (...) extending beyond the notion of "historic centre" or "ensemble" to include the broader urban context and its geographical setting (point 8). This wider context includes notably the site's topography, geomorphology, hydrology and natural features, its built environment, both historic and contemporary, its infrastructures above and below ground, its open spaces and gardens, its land use patterns and spatial organisation, perceptions and visual relationships, as well as all other elements of the urban structure. It also

\footnotetext{
${ }^{4}$ It should not be forgotten that the HULs are seen as "an innovative way of conserving heritage" (King, 2017: 15) and a "regulatory tool" (Paris Recommendation, 2011, art. 24.C), receiving the attention of multiple disciplines and geographers, urban planners, architects, planners, anthropologists or sociologists who discuss heatedly on the decisive role of heritage and cultural landscapes in the future design of our cities.
}

ACE, 15 (43) CC BY-ND 3.0 ES | UPC Barcelona, España | Landscape and Urbanism in the 21st Century. Some Reflections 5 on the State of Affairs. DOI: http://dx.doi.org/10.5821/ace.15.43.8987 
includes social and cultural practices and values, economic processes and the intangible dimensions of heritage as related to diversity and identity" (point 9).

As we mentioned earlier, "the drafters of the Recommendation only needed to include the submarine world to ensure that the concept of Historic Urban Landscape was delimited by land, sea and air" (Azkarate and Azpeitia 2016, p. 317).

To make matters worse, Recommendation CM/REC(2017)7 passed on 27 September 2017 by the Committee of Ministers of the member states of the signed up to the European Convention (Council of Europe), recently complicated things unnecessarily with their good intentions by reminding us of the importance for society of the diversity and quality of landscapes, stressing the realisation of human rights and democracy with a view to sustainable development ${ }^{5}$, and reminding us of the need to ensure the participation of local and regional authorities and other relevant parties, including nongovernmental organizations and, of course, citizens, when defining, implementing, and monitoring landscape policies ${ }^{6}$. The Council of Europe working group put together on the occasion of the European "Landscape and Democracy" Convention held on October 19, 2016, had already established principles regarding the development of public participation processes geared to defining and implementing landscape policies. These extremely generic guidelines obviously do not solve the methodological complexity involved in developing truly effective participatory processes.

\section{Final Thoughts}

The Recommendation on the Historic Urban Landscape (UNESCO, Paris, 2011) probably falls into naive voluntarism by believing that "the approach based on the historic urban landscape implies the application of a range of traditional and innovative tools adapted to local contexts. Some of these tools need to be developed as part of the process involving the different stakeholders". After a few years, it must be said that the methodological development necessary to respond to the needs arising from the current context is still lacking, especially when it comes to dealing with the dynamics of "change management" required in a 21st-century city. The very concept of landscape (cultural) and the more specific concept of historic urban landscape entail the incorporation of a multidimensional context that is easy to conceptualize, but difficult to manage for various reasons and circumstances that, without wishing to be exhaustive, we will synthesize in the following items.

\subsection{The survival of Weberian models}

The conceptual convergence around the notion of landscape has not yet seen a similar concurrence in the administrative sphere, which, in general, continues to suffer the consequences of sectoral management models and inertia. The Weberian organizational model of public administrations (still predominant) can be seen in urban planning policies based on a single-centre city layout, where the historic centre has always played a leading role as the visible remains of the formal features corresponding to the origins of the city, and as the preferred monumental space to concentrate the seats of political, economic and religious power. This fact has fostered the development of urban management strategies aimed at restoration, rescue, renovation, etc. All these terms allude to the interest in preserving these central areas and their architectural heritage.

\footnotetext{
${ }^{5}$ CM/REC(2017)7, a. "The importance that quality and diversity of landscapes has for the minds and bodies of human beings, as well as for societies, in the reflections and work devoted to human rights and democracy, with a view to sustainable development."

6 "guarantee the right to participation by the general public, local and regional authorities, and other relevant parties including non-governmental organizations, with an interest in the definition, implementation and monitoring of landscape policies."
}

ACE, 15 (43) CC BY-ND 3.0 ES | UPC Barcelona, España | Landscape and Urbanism in the 21st Century. Some Reflections 6 on the State of Affairs. DOI: http://dx.doi.org/10.5821/ace.15.43.8987 
In today's city, however, life is distributed into a plurality of networks arranged around multiple relational spaces that define the contemporary urban world as a clear example of a complex system. In this context, the new interconnected global public space demanded by contemporary societies far surpasses the architectural canon of a traditional city based on the centre-periphery layout (Camponeschi, 2012).

\subsection{Regulatory inertia}

It must be acknowledged that it is difficult to manage a contemporary city through traditional protection regimes regulated under current regulations. Along with the new tools and strategies that are being demanded, we should also require that the legal protection regimes adapt to the new demands for protection (a trend that is beginning to be appreciated - albeit very slowly - in the Spanish autonomous legislative framework in the field of cultural heritage, with the fourth generation of laws) ${ }^{7}$. The current regulatory shortcomings are causing a lack of protection for large parts of the contemporary urban heritage, which lies in the hands of the real estate market, with the obvious problems of destruction and banalisation derived from such a situation (Español, 2006; Nogué, 2007 and Muñoz, 2008).

Beyond the usual cataloguing and inventories - still aimed at protecting the 19th-century concept of heritage - it must be assumed that ordinary landscapes -the Heritage of the Ordinary-, require new assessment strategies that focus on rescuing collective items and the social empowerment based on the relationship with the landscape on a local scale. In short, it is a question of going far beyond the traditional idea linked to the exceptional uniqueness of cultural heritage, to strongly embrace, among other aspects, the sense of a collective identity as a testimony to the culture of a place that reflects human interaction over a territory over time.

\subsection{The indicators}

The development of indicator systems has become an experimental field within the framework of the discussion on new heritage strategies for the 21st century. There is copious scientific literature on indicators, with economic, social and environmental indicators being the most highly developed fields. Around the 1990s, there were a number of outstanding papers, such as Opschoor et al. (1991); Adriaanse (1994); Bakkes et al. (1994); Alberti (1996); Gallopin (1997); Strange (1997); Fricker (1998); Daly (1999); Kuik \& Gilbert (1999), and Nijkamp et al., (2000). Also, during this decade, at the international level, the Organisation for Development Cooperation participated in the methodological implementation of indicator systems, establishing general criteria governing how they were defined: Political Relevance-Utility, Analytical Soundness and Measurability (OECD, 1993).

In addition, their basic functions were specified: Simplification, Quantification and Communication (OECD, 1997). Along these lines, numerous conferences have been promoted by the World Heritage Centre (UNESCO) since 1990, highlighting the synthesis of indicators carried out at the Colonia del Sacramento Expert Meeting (Uruguay 1998), which focused on the conservation of historical heritage through the recognition of urban, architectural, environmental-landscape, social and cultural values. Some of the first proposals promoted by UNESCO itself in the specific field of historic urban landscapes were put forward at the workshop held in Chandigarh in $2007^{8}$ or at the convention held

\footnotetext{
7 The first division by generations applied to the autonomic regulatory analysis was prepared by Querol (2010). Later, other authors, such as Alonso Ibáñez (2014), have established various generational classifications.

${ }^{8}$ Workshop on the Management of Historic Urban Landscapes of the 20th Century, 18-21 December 2007, Chandigarh, (India).
}

ACE, 15 (43) CC BY-ND 3.0 ES | UPC Barcelona, España | Landscape and Urbanism in the 21st Century. Some Reflections 7 on the State of Affairs. DOI: http://dx.doi.org/10.5821/ace.15.43.8987 
in St. Petersburg in the same year ${ }^{9}$. The conclusions of this latter event included a line of work based on four sets of key indicators with the aim of analysing the evolution of historic urban landscapes while promoting urban planning policies that prioritise conservation and sustainable development.

With a more restricted scope regarding the field of historic centres, a discussion group was created to implement management policies in World Heritage cities in April 2009, promoted by the World Heritage Centre and the UNESCO Regional Office in Cuba. The result was the development of the "Indicators of Sustainable Conservation in Historic World Heritage Centres" project, which proposed a system divided into three levels. More recently, the so-called "City Prosperity Initiative" (CPI) prepared by UN-Habitat in 2012, where political dialogue and data monitoring come together with two clearly marked objectives, stands out as a benchmark: 1. Create a strategic policy planning tool where information is adapted to contextual needs at different scales. 2. Establish global analogies by promoting knowledge transfer and mutual learning ${ }^{10}$. The latest of the documents we can bring up, the aforementioned Recommendation CM/REC(2017)7 (point h), stresses once again the need to include the concept of landscape in "indicators of sustainable development relating to environmental, social, cultural and economic issues"11.

Despite all these tips and warnings, indicators are still an ongoing issue. The UNESCO Recommendation on the Historic Urban Landscape (Paris 2011) advocates sustainable practices through the multidisciplinary analysis of urban contexts, but this requires the provision of specific tools to manage change and new tools to evaluate different alternatives based on their multidimensional impacts. To date, identifying and using indicators linked to the sustainability of the natural heritage has had some success (Pelt 1933; Agenda 21 (ONU-UNCED 1992); OCED 1994; Azar et al. 1996; Blue book (UNCSD, 1996); Dhal 1996 y 2011; Moldan et al. 2007; Moldan et al. 2012; Bastiatoni et al. 2012; Layke et al. 2012; and Guzman et al. 2018), but we are still far from achieving truly homogeneous indicators in terms of urban conservation and cultural heritage. The challenge is not easy. Establishing shared evaluation criteria for historic cities and urban landscapes can only be achieved with generic indicators; it is absolutely unfeasible when using all those specific indicators adapted to the particular needs of each case. Consequently, the scope and depth of these shared benchmarks run the risk of being superficial and limited.

\subsection{Tactical urbanism}

Urban landscapes born in the context of new globalism are increasingly complex and, consequently, they are in need of urgent alternatives that respond to the dramatic structural models used. In recent decades, there has been a significant boom in what has been called tactical or ephemeral urbanism (see Figure 1 for its most characteristic features), which stands as a challenge against contemporary hierarchical urban planning processes to which we referred when we mentioned the dominant Weberian administrative trends still found in today's institutions.

\footnotetext{
${ }^{9}$ Regional Conference on "Application of Scientific and Technological Achievements in the Management and Preservation of Historic Cities inscribed on the World Heritage List" (UNESCO, January-February 2007).

10 In 2015, UN-Habitat published the "Global City Report" with the results obtained from the application of the Urban Prosperity Initiative tool in 60 different cities spread over all continents.

${ }^{11}$ Apart from the efforts made at the international level by non-governmental organisations, it is interesting to highlight other contributions, such as the views of Hugnoy and Roca (2008) which define a list of 74 indicators that combine urban sustainability with the list of indicators defined at the aforementioned meeting at Colonia del Sacramento (UNESCO 1998). Also noteworthy is the project launched by the Andalusian Historical Heritage Institute (IAPH) to develop indicators in historic cities inscribed on the World Heritage List (AA. VV, 2009 and 2011). As very recent contributions, with an updated bibliography, you can see Guzman et al. (2017 and 2018).
}

ACE, 15 (43) CC BY-ND 3.0 ES | UPC Barcelona, España | Landscape and Urbanism in the 21st Century. Some Reflections 8 on the State of Affairs. DOI: http://dx.doi.org/10.5821/ace.15.43.8987 

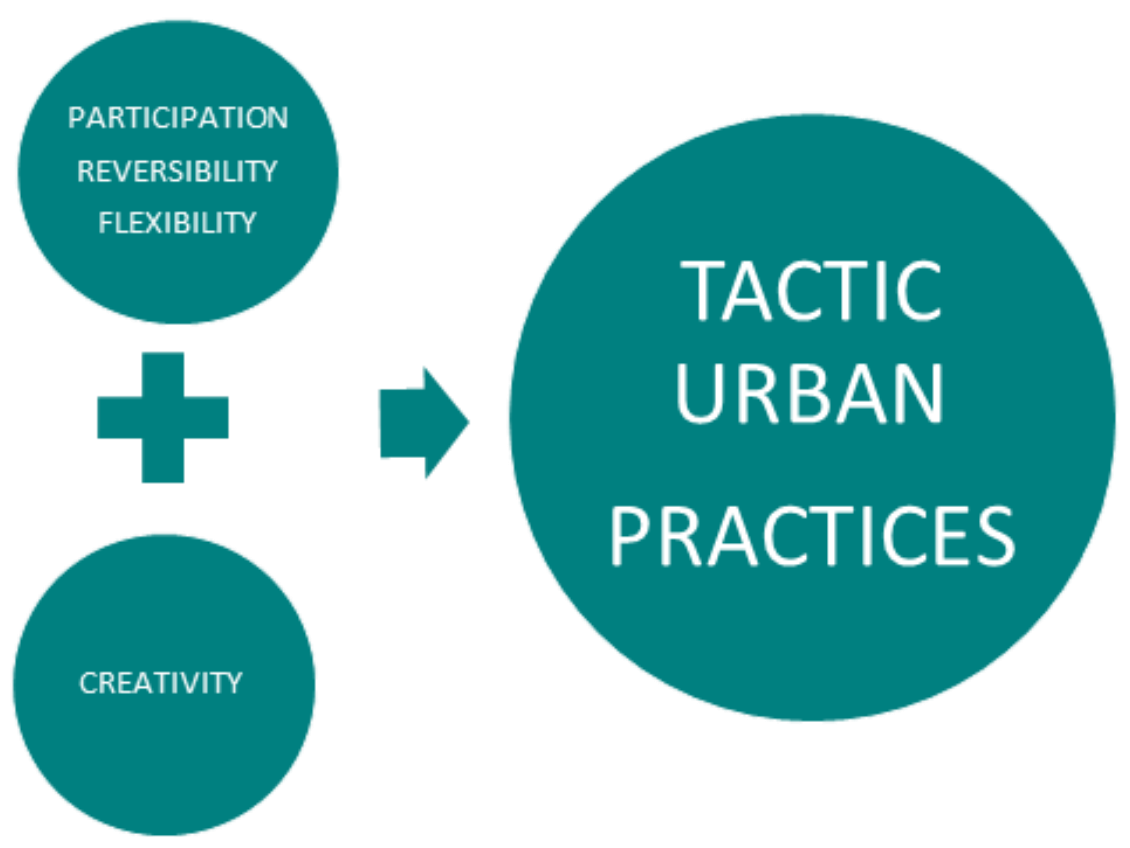

PARTICIPATION

REVERSIBILITY

FLEXIBILITY

\begin{tabular}{|l|l|l|}
\hline $\begin{array}{l}\text { Citizen participation is the key } \\
\text { aspect throughout the entire } \\
\text { process. }\end{array}$ & $\begin{array}{l}\text { Actions subject to an outcome } \\
\text { assessment: if not positive, it is } \\
\text { eliminated. }\end{array}$ & $\begin{array}{l}\text { Superficial actions with limited } \\
\text { impact at a structural level. }\end{array}$ \\
\hline Bottom- up projects. & Low-cost actions. & Easily modifiable actions. \\
\hline $\begin{array}{l}\text { Creativity, knowledge generation, } \\
\text { transdisciplinarity. }\end{array}$ & $\begin{array}{l}\text { Quick, developed, short-term } \\
\text { actions. }\end{array}$ & $\begin{array}{l}\text { Actions that are constantly being } \\
\text { reviewed and updated. }\end{array}$ \\
\hline
\end{tabular}

In the mid-20th century, Jane Jacobs, in one of the most influential critical works in the field of contemporary urban planning, stated that "Cities are an immense laboratory of trial and error, failure and success, in city building and city design" (1961, pag. 6). This seminal idea has been strongly embraced by tactical urbanism through the development of simple, low-budget actions with few administrative requirements where the key lies in the reversibility of the actions taken, a factor that makes it possible to assess the degree of success or failure with a view to their future implementation or rectification. "Tactical urbanism can be applied to the arterials, parking lots and cul-de-sacs of America. Yet, the best examples are consistently found in compact towns and cities featuring an undervalued/underutilized supply of walkable urban fabric" (Lydon, 2012, pag. 3). Most of these actions focus on underutilized urban public spaces on which strategies promoted by the residents themselves are tested, opening up new possibilities for their reuse in a more coherent way in tune with the way the citizens feel about and value their city. In line with this idea, Stickells defines tactical urbanism as "a series of microspatial urban practices that redirect the use of city spaces in order to reverse the dynamics of certain urban environments" (2011, pag. 223).

In this way, the traditionally passive role played by citizens is reversed and they play an active role in the management and improvement processes in their neighborhoods through projects generated from the "bottom up" with an outstanding level of involvement from the outset of the project. All this

ACE, 15 (43) CC BY-ND 3.0 ES | UPC Barcelona, España | Landscape and Urbanism in the 21st Century. Some Reflections 9 on the State of Affairs. DOI: http://dx.doi.org/10.5821/ace.15.43.8987 
can be perfectly encompassed in the not as young as one thinks (McLuhan and Nevitt, 1972) prosumer spirit. The origin of this prosumer thinking is linked to the field of economics, merging the terms "producer" and "consumer" in reference to individuals who generate and consume their products without the need for intermediaries. In the 1980s, Toffler emphasised that "until the industrial revolution, the vast bulk of all the food, goods, and services produced by the human race was consumed by the producers themselves [or] their families" (1980, pag. 37). Today, our globalised -and paradoxically more and more individualistic- society has found in the development of the new information technologies the ideal breeding ground to generate a different type of prosumer: citizens with many skills who, mainly through social media, produce and consume information. This is a new concept of prosumer that has its roots in the paradigm of participatory and creative culture as a producer of critical content (García-García and Gil-Ruiz, 2019)12.

Although tactical urbanism is not considered to be an instrument of urban or territorial planning ${ }^{13}$, the relevance of its participatory nature and the actual involvement of citizens in the decision-making is what makes it particularly attractive ${ }^{14}$. Tactical urbanism offers a high response capacity to the continuous demand for quality public spaces, a problem that is one of the priority objectives set out in the "New 2030 Agenda for Sustainable Development" adopted at the "HABITAT III World Conference on Housing and Sustainable Urban Development. ${ }^{15}$ We want to believe that short-term planning can provide valuable information to develop large-scale projects, favour data collection, analysis and reach conclusions. As Lange (2012) points out, lighter, faster and cheaper strategies aimed at bringing public space to life in the short term can be an extraordinarily effective way of building community support for larger projects. However, as these actions are promoted by empowered people who are not experts in the field, i.e. since this is "citizen urbanism", the challenge is to recognise the value of these informal actions in the public space to promote and incorporate them into the development of new inclusive long-term urban management and planning policies. ${ }^{16}$

\section{Acknowledgments}

This contribution is part of the research project "Archaeology of Architecture: new methodological challenges and their application in Europe and Latin America" (HAR2915-64439-P), financed by the Spanish Ministry of Economy and Competitiveness and the European Regional Development Fund (ERDF).

\section{Authorship}

The first author has made substantial contributions to the conception of the paper; the second and the third author have drafted the paper and have revised it critically for important intellectual content.

\footnotetext{
12 The empowerment of citizens through the development of social networks has allowed new prosumers to "generate more public information than organisations. Through social media and blogs, prosumers assume the leading role in the information and knowledge society, surpassing the institutions" (Islas and Arribas, 2010: 153-154). In the urban area, "data generated in social networks used for urban study purposes provide a valuable opportunity to address issues such as: the use and preference for certain activities and places; the image and perception of urban spaces; spatiotemporal patterns of people presence and urban space-use; supply and demand of economic activity; and, identification of areas of concentration and specialization in the city". (Martí Ciriquián et al., 2019: 83).

13 Tactical urbanism is catalogued as an indicative, not regulatory, urban management tool. The regulatory or imposing instruments are those that have the necessary legal backing to develop prescriptive regulations, while "indicative planning does not have the power of imposition, but is attractive for economic and social stakeholders and can have consequences in the organisation of the territory" (Sánchez, 2014: 110).

${ }^{14}$ In this regard, the workshops developed recently in the city of Barcelona by Sève and Redondo (2019) are very interesting. ${ }^{15}$ Chapter 7 of Section B of Part II of the "Global Report on Culture for Sustainable Urban Development" (UNESCO, 2016).

${ }^{16}$ We are aware of the difficulties involved in this challenge, since "any transitory solution is a rare occurrence in urban actions, because planning flees from these grey areas where decisions are not linked to the production of urban spaces and resources, but to temporary balances in which solutions and regulations have to adapt over time in a flexible manner" (Fernandez, 2014).
}

ACE, 15 (43) CC BY-ND 3.0 ES | UPC Barcelona, España | Landscape and Urbanism in the 21st Century. Some Reflections 10 on the State of Affairs. DOI: http://dx.doi.org/10.5821/ace.15.43.8987 
Conflict of interests: Authors declares no conflict of interests.

\section{Bibliography}

Adriaanse, A. (1994). A Conceptual Framework for Sustainable Development Indicators. In Network Seminar on Sustainable Development Indicators. London, England.

Alberti, M. (1996). Measuring urban sustainability. Environmental Impact Assessment, 16(4-6), 381-424. DOI: https://doi.org/10.1016/S0195-9255(96)00083-2

Alonso Ibáñez, M.R. (2014). La tercera generación de Leyes de Patrimonio Histórico. Patrimonio Cultural y Derecho, 18, 11-28.

Azar, C.; Holmberg, J. and Lindgren, K. (1996). Socio-ecological indicators for sustainability. Ecological economics, 18(2), 89-112. DOI: https://doi.org/10.1016/0921-8009(96)00028-6

Azkarate, A. and Azpeitia, A. (2016). Paisajes urbanos históricos ¿Paradigma o Subterfugio? In Jurkovic M. And Chavarria, A. (ed) Alla ricerca di un passato complesso. Contributi in onore di Gian Piertro Brogiolo per il suo settentesimo compleanno (pp. 307-326). Zagreb, Croatia: IRCLAMA, University of Zagreb.

Bakkes, J.A.; Van Den Born, G.J.; Helder, J.C., Swart, R.J.; Hope, C.W.; Parker J.D.E. (1994). An Overview of Environmental Indicators: State of the Art and Perspectives, Report No UNEP/EATR9401RIVM/402001001.

Bandarin, F. and Van Oers, R. (2014). El Paisaje Urbano Histórico. La gestión del Patrimonio en un Siglo Urbano. Madrid, Spain: Abad editors.

Bastiatoni, S.; Niccolucci, V.; Puselli, R.M.; and Marchettini, N. (2012). Indicator and indicandum: "Sustainable way" vs "prevailing conditions" in the Ecological Footprint. Ecological Indicators, 16, 4750. DOI: https://doi.org/10.1016/j.ecolind.2011.10.001

Camponeschi, C. (2012). Creative Problem-Solving and the Power of the Everyday. Toronto, Canada: Creative Commons (CC).

Caraballo Perichi, C. (2009). Volviendo a los indicadores. La cuantificación de los criterios patrimoniales. ¿Un objetivo alcanzable? In Salmerón, P. and Sanz, N. (ed) El Paisaje Urbano Histórico en las ciudades históricas patrimonio mundial. Indicadores para su conservación y Gestión (pp. 5869). Sevilla, Spain: Consejería de Cultura.

Carapinha, A. (2009). Los tiempos del paisaje. In Maderuelo, J. (ed) Paisaje e Historia (pp.123-141). Madrid, Spain: Abada Editores.

Choay, F. (1992). L'allégorie du Patrimoine. Paris, France: Editions du Seuil.

Conti, A. (2009). Paisajes históricos urbanos: nuevos paradigmas en conservación urbana. Patrimonio: Economía Cultural y Educación para la Paz (MEC-EDUPAZ), 2(10), 1-12. Retrieved from http://www.revistas.unam.mx/index.php/mecedupaz/article/view/57138

ACE, 15 (43) CC BY-ND 3.0 ES | UPC Barcelona, España | Landscape and Urbanism in the 21st Century. Some Reflections on the State of Affairs. DOI: http://dx.doi.org/10.5821/ace.15.43.8987 
Council of Europe (2018). Council of Europe Landscape Convention. Contribution to human rights, democracy and sustainable development. Retrieved from https://rm.coe.int/council-of-europelandscape-convention-contribution-to-human-rights-de/16807bffda

Daly, H. (1999) Ecological Economics and the Ecology of Economics: Essays in Criticism. Maryland, USA: Edward Elgar.

Español, I. (2006). La recuperación del valor del paisaje urbano. Una respuesta a la banalización desde las identidades del universo metropolitano. Ingeniería y Territorio, 75, 10-17.

Fernández, M. (2014). Obsolescencia, temporalidad y permanencia en la ciudad en crisis. Revista digital La Ciudad Vivida.

Fricker, A. (1998). Measuring up to sustainability. Futures, 4, 367-375. DOI: https://doi.org/10.1016/S0016-3287(98)00041-X

Gallopin, G. (1997). Indicators and their use: information for decision-making. Sustainability indicators: Report of the project on indicators of sustainable development. Moldan, B. \& Billharz, S (Eds.), Chichester, UK: John Wiley \& Sons.

Guzman, P.C.; Pereira Roders, A.R. \& Colenbrander, B.J.F. (2018). Impacts of Common Urban Development Factors on Cultural Conservation in World Heritage Cities: An Indicators-Based Analysis. Sustainability, 10(3), 853. ODI: https://doi.org/10.3390/su10030853

Giovannoni, G. (1931). Vecchie città ed edilizia nuova. Roma, Italy: Tipografica Editrice.

Groth, P. \& Bressi, T.W. (1997). Understanding Ordinary Landscapes. Yale, USA: University Press.

Moldan, B. \& Dahl, A.L. (2007). Challenges to Sustainability Indicators. Sustainability Indicators: A Scientific Assessment, SCOPE 67, 1.

Islas, O. \& Arribas, A. (2011). Comprender las redes sociales como ambientes mediáticos. In the project Facebook y la post-universidad. Sistemas operativos sociales y entornos abiertos de aprendizaje. Madrid, Spain: Ariel.

Jacobs, J. (1961). The death and life of great American cities. New York, USA: Random House.

Jokilehto, J. (1999) A History of Architectural Conservation. Oxford, England: Elsevier.

Kuik, O. \& Gilbert, A. (1999). Indicators of sustainable development. In van den Bergh, J. C.J.M. Handbook of Environmental and Resource Economics (pp. 722-730). Cheltenham, England: Edward Elgar.

Lalana Soto, J.L. (2011). El Paisaje Urbano Histórico: modas, paradigmas y olvidos. Ciudades: Revista del Instituto Universitario de Urbanística de la Universidad de Valladolid, 14(1), 15-38.

Lange, A. (2012). The power of a ping pong table. Report of the project for Public Spaces. Retrieved from https://www.pps.org/blog/the-power-of-a-ping-pong-table/ 
Layke, C.; Mapendembe, A.; Brown, C.; Walpole, M. \& Winn, J. (2012). Indicators from the global and sub-global Millennium Ecosystem Assessments: An analysis and next steps. Ecological Indicators, 17, 77-87. DOI: https://doi.org/10.1016/j.ecolind.2011.04.025

Luginbühl, Y. (1989). Paysage élitaire et paysages ordinaires. Ethnologie française, XIX, 3, 227-238.

Lydon, M. (2012). Urbanismo táctico 2. Acción a corto plazo, cambio a largo plazo. New York, USA. Street Plans Collaborative. Retrieved from https://issuu.com/streetplanscollaborative/docs/urbanis mo tactico 2 digital edition

Martí Ciriquián, P.; Nolasco-Cirugeda, A. \& Serrano-Estrada, L. Los datos geolocalizados de las redes sociales en el estudio de cuestiones urbanas complejas: cinco temas, cinco redes. ACE: Architecture, City and Environment, 14(41), 83-108, 2019. DOI: https://dx.doi.org/10.5821/ace.14.41.8217

Mcluhan, M. \& Nevitt, B. (1972). Take to-day: The Executiveas Dropout. New York, USA: Harcourt Brace Jovanovich.

Moldan, B. \& Janouskova, S. (2012). How to understand and measure environmental sustainability. Ecological Indicators, 17, 4-13. DOI: https://dx.doi.org/10.1016/j.ecolind.2011.04.033

Muñoz, F. (2008). Urbanalización. Paisajes comunes, lugares globales. Barcelona, España: Gustavo Gili, SL.

Muñoz, F. (2010). Los paisajes del transumer. El orden visual del consume en tránsito. Enrahonar, 45, 107-121.

Nijkamp, P. \& Vreeker, R. (2000), Sustainability assessment of development scenarios: methodology and applications to Thailand. Ecological economics, 33, 7-27. DOI: https://dx.doi.org/10.1016/S09218009(99)00135-4

Nogué, J. (2007). Territorios sin discurso, paisajes sin imaginario. Retos y dilemas. ERíA Revista cuatrimestral de Geografía, 73-74, 373-382. Retrieved from https://www.unioviedo.es/reunido/index.php/RCG/article/view/1593/1508

Opschoor, H. \& Reijnders, L. (1991) Towards sustainable development indicators. In Kuik, O.J. and Verbruggen, $H$. (ed) In search of indicators of sustainable development. Retrieved from https://www.google.com/search?q=Opschoor\%2C+H.+\%26+Reijnders\%2C+L.+\%281991\%29+Towards + sustainable+development+indicators. + In+Kuik\%2C+O.J.+and+Verbruggen\%2C+H.+\%28ed\%29+In+se arch+of+indicators+of+sustainable+development.+DOI\%3A+10.1007\%2F978-94-011-3246-6\&ie=utf8\&oe=utf-8\&client=firefox-b-ab

Papadam, M. (2017). Heritage of the ordinary: an alternative view Strategies for using cultural heritage sites as a driver of sustainable urban [re] development in Piraeus. Delft University of Technology Faculty of Architecture and the Built Environment, Netherlands. Retrieved from http://resolver.tudelft.nl/uuid:2fe6298c-c5ac-4791-ac3f-99deda957eb4

Pelt, M.V. (1993). Ecological sustainability and sustainable development. Aldershot, UK: Avebury.

Querol, M.A. (2010) Manual de Gestión del Patrimonio Cultural. Madrid, Spain: Akal.

ACE, 15 (43) CC BY-ND 3.0 ES | UPC Barcelona, España | Landscape and Urbanism in the 21st Century. Some Reflections on the State of Affairs. DOI: http://dx.doi.org/10.5821/ace.15.43.8987 
Sánchez de Juan, J. (2000) La Destrucción Creadora: El Lenguaje de la reforma urbana en tres ciudades de la Europa mediterránea a finales del S. XIX (Marsella, Nápoles y Barcelona). Scripta Nova, 63. Retrieved from http://www.ub.edu/geocrit/sn-63.htm

Sánchez Ulloa, R. (2014) Ordenamiento territorial de Santiago. Departamento Administrativo de Planeación Municipal Subdirección del POT y Servicios Públicos. Retrieved from https://www.academia.edu/23063391/DOCUMENTO T\%C3\%89CNICO DE SOPORTE REVISI\%C3\%93 N ORDINARIA DEL PLAN DE ORDENAMIENTO TERRITORIAL DE SANTIAGO DE CALI Departament o Administrativo de Planeaci\%C3\%B3n Municipal Subdirecci\%C3\%B3n del POT y Servicios P\%C3 \%BAblicos

García-García, F.; Gil-Ruiz J.I. (2019). Digital journalism and empowerment. Informational trends in Google news during 2017. Mediterranean Journal of Comunication, 10(2). DOI: https://www.doi.org/10.14198/MEDCOM2019.10.2.10

Sansot, P. (1989). Pour une esthétique des paysages ordinaires. Ethnologie Française (Crise du paysage), 3, 239-244.

Santamarina, B. (2017). El patrimonio inmaterial en el País Valenciano: una explosión muy tangible. Revista Andaluza de Antropología, 12, 117-143. DOI: https://dx.doi.org/10.12795/RAA.2017.12.06

Sève, B. \& Redondo, E. (2020). El pabellón de deseos. Co-creación y co-instalación artística para la mejora del espacio público. ACE: Architecture, City and Environment, 14(42), 8200. DOI: https://dx.doi.org/10.5821/ace.14.42.8200

Smith, L. (2006). Uses of Heritage. London and New York: Routledge.

Smith, N. (2001). Nuevo globalismo, nuevo urbanismo. Documents d'anàlisi geogràfica, 38, 15-32. Retrieved from https://dialnet.unirioja.es/servlet/articulo?codigo=226229

Stickells, L. (2011). The Right to the City, Rethinking Architecture's Social Significance. Architectural Theory Review, 16(3), 213-227. DOI: https://doi.org/10.1080/13264826.2011.628633

Strange, I. (1997). Planning for change, conserving the past: towards sustainable development policy in historic cities? Cities, 14(4), 227-233. DOI: https://doi.org/10.1016/S0264-2751(97)00007-3

Toffler, A. (1980). The third wave. USA: Willian Morrow \& Company.

UNCED (1992). Rio Declaration on Environment and Development, Report of the United Nations Conference on Environment and Development, August 12, 1992, A/CONF.151/26 (Vol.1).

ACE, 15 (43) CC BY-ND 3.0 ES | UPC Barcelona, España | Landscape and Urbanism in the 21st Century. Some Reflections on the State of Affairs. DOI: http://dx.doi.org/10.5821/ace.15.43.8987 